Revue des patrimoines

\title{
LE NUMERO EN BREF - Architecture et patrimoine des frontières. Entre identités nationales et héritage partagé
}

The architecture and heritage of frontiers, between national identities and shared heritage

Responsables scientifiques : Hervé Doucet et Marie Pottecher

\section{OpenEdition}

Journals

Édition électronique

URL : http://journals.openedition.org/insitu/20995

DOI : 10.4000/insitu.20995

ISSN : 1630-7305

Éditeur

Ministère de la culture

Référence électronique

Responsables scientifiques : Hervé Doucet et Marie Pottecher, «LE NUMERO EN BREF - Architecture

et patrimoine des frontières. Entre identités nationales et héritage partagé », In Situ [En ligne],

38 | 2019, mis en ligne le 18 février 2019, consulté le 01 mai 2019. URL : http://

journals.openedition.org/insitu/20995 ; DOI : 10.4000/insitu.20995

Ce document a été généré automatiquement le 1 mai 2019.

In Situ Revues des patrimoines est mis à disposition selon les termes de la licence Creative Commons Attribution - Pas d'Utilisation Commerciale - Pas de Modification 4.0 International. 


\section{LE NUMERO EN BREF - Architecture et patrimoine des frontières. Entre identités nationales et héritage partagé}

The architecture and heritage of frontiers, between national identities and shared heritage

Responsables scientifiques : Hervé Doucet et Marie Pottecher

1 Les 13 articles qui composent ce numéro d'In Situ intitulé Architecture et patrimoine des frontières. Entre identités nationales et héritage partagé sont répartis en quatre sections qui proposent chacune, au travers d'études de cas, d'aborder ce patrimoine particulier sous un angle spécifique. Trois articles s'intéressent plus particulièrement à la question de l'identité nationale. Architecture et patrimoine y sont considérés comme des outils d'affirmation et de légitimation d'une identité. Cinq contributions se penchent sur la frontière et ses processus de patrimonialisation, essentiellement au cours de la seconde moitié $\mathrm{du} \mathrm{xx}{ }^{\mathrm{e}}$ siècle. Deux articles étudient la manière de marquer la frontière à l'occasion de son déplacement ou de son effacement dans des contextes historique et géographique éloignés : l'Europe, au lendemain de la Première Guerre mondiale, et l'Asie de la seconde moitié $\mathrm{du} \mathrm{xx} \mathrm{x}^{\mathrm{e}}$ siècle. Enfin, trois articles sont consacrés à l'Alsace, une région qui, compte tenu de son histoire, est particulièrement concernée par la question de la frontière et de ses changements. Certains projets architecturaux et urbains récents ou en cours de réalisation peuvent être compris comme des réponses à cette histoire mouvementée.

Ce numéro ne prétend pas dresser un panorama exhaustif du patrimoine des frontières mais a pour ambition d'esquisser certaines pistes pour des recherches futures sur une question d'une actualité brûlante.

The architecture and heritage of frontiers, between national identities and shared heritage 
4 The thirteen articles which comprise this issue of In Situ, entitled 'The architecture and heritage of frontiers, between national identities and shared heritage' are divided into four sequences each of which presents case studies which help approach this heritage from different viewpoints. Three articles are primarily concerned by questions of national identity; architecture and heritage are considered as instruments which can affirm and legitimise an identity. Five contributions look at frontiers themselves and processes of heritage recognition - 'heritagisation' - essentially during the second half of the twentieth century. Two articles then study the way frontiers are marked when they move or when they disappear, in distant historical or geographical contexts. Three articles, finally, address the issue in Alsace, a region which, on account of its history, is particularly concerned by these questions of frontiers and the way they shift. In recent years, certain architectural and town-planning projects may be understood as responses to the region's turbulent history.

5 This issue of the review does not pretend to offer a complete panorama of frontier heritage, but it hopes to suggest some lines of enquiry for future research on a question which is of burning topicality. 